\title{
Pengaruh Model Pembelajaran Kooperatif Type STAD Terhadap Keterampilan Pengisian Partograf Mahasiswa Kebidanan
}

\author{
Yulizawati $^{1 *}$, Venny Rismawanti ${ }^{2}$ \\ ${ }^{1}$ Prodi S1 Kebidanan Universitas Andalas \\ ${ }^{2}$ Akademi Kebidanan Indragiri
}

Informasi Artikel:

Diterima: Mei, 2015

Disetujui: Oktober, 2015

${ }^{*}$ Korespondensi penulis. yulizawati@yahoo.co.id

\begin{abstract}
ABSTRAK
Pengembangan pendidikan menuntut adanya cara berfikir dan bertindak yang berbeda dari apa yang telah ada. Sistim pembelajaran yang baik harus mampu memberikan pengalaman belajar kepada mahasiswa untuk membuka potensi dirinya dalam menginternalisasikan knowledge, skills dan attitudes melalui pengalaman belajarnya. Untuk mencapai hal tersebut dapat dilakukan dengan menerapkan pola pembelajaran aktif melalui student centered learning (SCL) yang salah satunya adalah tipe STAD (Student Teams Achievement Division) karena tipe ini mengajarkan kerjasama, tanggung jawab, interaksi promotif, kepercayaan, pembuatan keputusan, komunikasi dan manajemen konflik. Dengan metode STAD, penguasaan pengisian partograf sebagai kompetensi inti dari mahasiswa kebidanan dalam pemantauan persalinan dapat meningkat.
\end{abstract}

Tujuan dari penelitian ini adalah untuk mengetahui bagaimana pengaruh dari metode STAD terhadap keterampilan mahasiswa dalam pengisian partograf. Metode yang dipakai penelitian ini adalah penelitian komparasi untuk membandingkan tingkat penguasaan keterampilan pengisian partograf sebelum dan sesudah penggunaan metode kooperatif tipe STAD. Hasil yang diperoleh pada penelitian ini yaitu terdapat perbedaan yang sangat signifikan pada tingkat penguasaan keterampilan mahasisa dalam mengisi partograf antara sebelum dengan sesudah penggunaan model pembelajaran kooperatif tipe STAD dengan nilai $p=0,001$. Metode pembelajaran student centered learning (SCL) dengan tipe STAD terbukti signifikan dalam peningkatan kompetensi mahasiswa dalam pengisian partograf.

Kata kunci: Partograph, Keterampilan, STAD

\begin{abstract}
Educational development demands different ways of thinking and act from what have already existed. Ideal learning system must be able to provide a learning experience for students, to open up their potential for internalizing knowledge, skills and attitudes through their learning experiences. It can be done by applying an active learning method through student centered learning (SCL), one of these methods is STAD (Student Teams Achievement Division). This type teaches cooperation, responsibility, interaction, confidence, decision-making, communication, and conflict management. With this method, partograph filling skill as the core competencies of midwifery students in labor monitoring may increase..
\end{abstract}

This research aims to determine the effect of STAD method on partograph filling skill of midwifery students. This was a comparative study to compare the level of student skill in filling up partograph before and after applying cooperative learning using STAD method. The results obtained in this study showed that there was a very significant difference of the skill of students before and after using cooperative learning of STAD method, with a p-value is 0.001 . Student centered learning using STAD method is proved to be more significant to improve student competence of filling up partograph.

Keywords: Partograph, skill, STAD 


\section{PENDAHULUAN}

Bidan sebagai salah satu tenaga kesehatan yang berperan dalam pencapaian universal health coverage 2019 harus di didik dalam suasana proses pembelajaran yang mampu menggali potensi dirinya baik hard skills ataupun soft skills dalam penguasaan kompetensi yang harus dimilikinya. Hal tersebut dapat dicapai dengan penerapan metode pembelajaran student centered learning yang menerapkan pola pembelajaran aktif melalui student centered learning ( $S C L)$, yang salah satunya adalah type STAD (Student Teams Achievement Division). Metode type ini melatih adanya kerjasama, tanggung jawab, interaksi promotif, kepercayaan, pengambilan keputusan, komunikasi dan manajemen konflik. Dengan metode STAD, penguasaan pengisian partograf sebagai kompetensi inti dari mahasiswa kebidanan dalam pemantauan persalinan dapat meningkat (Anderson, 2000, Bradley, 2011 dan LP3M Unand, 2014).

Bidan dalam melaksanakan asuhan persalinan harus selalu menggunakan partograf untuk memantau kemajuan setiap persalinan yang ditanganinya. Berdasarkan studi kasus yang dilakukan terhadap pengetahuan mahasiswa Akademi Kebidanan Indragiri semester $\mathrm{V}$ yang telah mempelajari secara teoritis tentang partograf, $95,7 \%$ mahasiswa yang berpengetahuan baik, dan ketika dilakukan praktek pengisian partograf secara perorangan 52,9\% memiliki keterampilan yang baik dalam pengisian partograf. Berdasarkan hal di atas, perlu dilakukan suatu metode yang lebih tepat sehingga keterampilan mahasiswa dalam mengisi partograf dapat meningkat.

Pendekatan dan konsep pada metode kooperatif type STAD menekankan penguasaan partograf sebagai hasil kelompok. pertama mahasiswa diberikan materi tentang partograf secara klasikal, kemudian dibagi menjadi 5-8 orang dalam setiap kelompok dengan kemampuan yang berbeda. Setiap anggota kelompok saling bertanggung jawab dalam penguasaan materi. Mahasiswa yang belum menguasai materi di bantu oleh teman dalam kelompoknya sehingga pada akhirnya seluruh anggota kelompok menguasai materi tentang partograf dan hasil tersebut akan menunjukkan hasil kelompok.

Pengujian hipotesis atau dugaan yang akan dibuktikan adalah terdapat perbedaan proporsi yang bermakna terhadap keterampilan pengisian partograf mahasiswa sebelum dan sesudah digunakan metode kooperatif type STAD (Dahlan, MS 2009). Uji hipotesis yang digunakan adalah uji Mc. Nemar karna jumlah pengulangan 2 dan kategorinya berjumlah 2. Jenis hipotesisnya adalah komparatif kategorik berpasangan (Dahlan, MS 2009).

Tujuan penelitian adalah untuk mengetahui pengaruh model pembelajaran kooperatif type STAD terhadap keterampilan mahasiswa dalam pengisian partograf. Penelitian ini dilaksanakan di salah satu Akademi Kebidanan di Rengat.

\section{BAHAN DAN METODE}

Penelitian ini menggunakan komparatif study tentang keterampilan pengisian partograf pada mahasiswi Akademi Kebidanan Indragiri Rengat sebelum dan sesudah penggunaan metode kooperatif Type STAD. Analisis data yang digunakan adalah analisis bivariat yang berupa korelatif kategorik dengan menggunakan t-test dan Mc.Nemar digunakan untuk uji hipotesis. Disain penelitian ini adalah correlation antara variabel Model Pembelajaran kooperatif type STAD dengan Keterampilan dalam pengisian partograf.

Penelitian ini menggunakan total populasi, yaitu seluruh mahasiswa salah satu akademi kebidanan di wilayah Rengat yaitu sejumlah 79 orang. Jenis data yang digunakan dalam penelitian adalah data primer dan data sekunder. Teknik pengambilan data dilakukan dengan menilai keterampilan responden terhadap pengisian partograf sebelum dan sesudah dilakukan model pembelajaran kooperatif type STAD. 


\section{HASIL DAN PEMBAHASAN}

Dibawah ini adalah hasil penelitian terkait sikap mahasiswa tentang pengisian partograf dibandingan sebelum dan sesudah menggunakan metoda STAD.

\section{Tabel 1}

Perbandingan sikap mahasiswa sebelum dan sesudah penggunaan metode STAD

\begin{tabular}{ccccc} 
& Rerata \pm sb & $\begin{array}{c}\text { Selisih } \\
\text { rerata } \pm \text { sb }\end{array}$ & $\begin{array}{c}\text { IK95\% } \\
\text { selisih rerata }\end{array}$ & Nilai p \\
\hline Sebelum & $70,78 \pm 5,72$ & $2,09 \pm 6,16$ & $0,87-3,31$ & 0,001 \\
Sesudah & $72,87 \pm 7,39$ & & & \\
\hline
\end{tabular}

Uji t berpasangan

Dibawah ini adalah hasil penelitian terkait keterampilan mahasiswa terkait pengisian partograf tentang pengisian partograf dibandingan sebelum dan sesudah menggunakan metoda STAD.

Tabel 2

Perbandingan keterampilan sebelum dengan sesudah penggunaan metode STAD

\begin{tabular}{llcccc}
\hline & & \multicolumn{2}{c}{ Keterampilan sesudah STAD } & \multirow{2}{*}{ Nilai } \\
\cline { 3 - 5 } & & $\begin{array}{c}\text { Tidak } \\
\text { terampil }\end{array}$ & $\begin{array}{c}\text { Tera } \\
\text { mpil }\end{array}$ & Total & $\mathrm{p}$ \\
\cline { 3 - 5 } sebelum & $\begin{array}{l}\text { Tidak } \\
\text { terampil }\end{array}$ & 3 & 29 & 32 & 01 \\
STAD & Terampil & 0 & 47 & 47 & \\
\hline & Total & 3 & 76 & 79 & \\
\hline
\end{tabular}

\#Uji McNemar

Berdasarkan tabel di atas, didapatkan nilai $p$ 0,001 yang berarti bahwa terdapat perbedaan yang sangat bermakna antara keterampilan mahasiswa sebelum dan sesudah menggunakan model pembelajaran kooperatif type STAD dalam pengisian partograf. Hal ini sesuai dengan teori yang dikemukakan oleh Sartain dalam Azwar (2000) bahwa sikap positif terbentuk oleh faktor komunikasi dengan orang lain (communication with other people). Banyak sikap individu yang terbentuk disebabkan oleh adanya komunikasi dengan orang lain, yang dalam hal ini merupakan komunikasi langsung. Faktor lain adalah media komunikasi yang digunakan dalam menyampaikan sikap dan situasi pada saat sikap dibentuk, sehingga dengan komunikasi dalam kelompok dan adanya tujuan bersama yang ingin dicapai dalam kelompok membuat mahasiswa lebih termotivasi dalam pengisian partograf. Perubahan sikap yang terjadi ini menurut McGuire terjadi oleh karena adanya pendekatan teori belajar atau materi yang dipelajari (Sarwono SW, 2005).

Hal ini sesuai dengan teori menurut Slavin (Slavin et all, 1985) bahwa penggunaan metode STAD, mengacu kepada hasil belajar kelompok mahasiswa karena dengan menggunakan metode pembelajaran kooperatif type STAD, mahasiswa dapat mengembangkan serta menggunakan keterampilan berfikir kritis dan kerjasama kelompok, menyuburkan hubungan antar pribadi yang positif antara mahasiswa, menerapkan bimbingan oleh teman, serta menciptakan lingkungan yang menghargai nilai-nilai ilmiah. Hal ini sesuai dengan teori Nadler bahwa keterampilan merupakan kegiatan yang memerlukan praktik sehingga harus sering dilatih.

\section{KESIMPULAN}

Berdasarkan hasil pengolahan data yang dilakukan, keterampilan mahasiswa Akademi Kebidanan Indragiri Rengat menunjukkan peningkatan yang sangat bermakna setelah menggunakan model pembelajaran kooperatif type STAD.

\section{DAFTAR PUSTAKA}

Anas M., 2014. Mengenal metodelogi pembelajaran Anderson LW, Krathwohl DR, et all. 2006. A taxonomy for learning, teaching, and assessing: a revision of Bloom's taxonomy of educational objectives. Longman: New York;

Atkinson RL, Smith E \& Bem DJ. Pengantar psikologi. $2^{\text {th }}$ ed. Jakarta; 2000

Azwar S., 2000 Sikap manusia teori dan pengukurannya. Yogyakarta: Pustaka Pelajar

Bradley MJ, Seidman RH, Painchaud SR., 2011. Saving Higher Education: The Integrated, Competency-Based Three-Year Bachelor's Degree Program 
Dahlan MS., 2009. Besar sampel dan cara pengambilan sampel dalam penelitian kedokteran dan kesehatan. Jakarta: Salemba medika

Lembaga pengembangan pendidikan dan penjaminan mutu (LP3M). 2014. Panduan praktis pelaksanaan student ceentered learning (SCL). LP3M Unand. Padang

Sarwono SW., 2005. Psikologi Sosial: Individu dan Teori-Teori Psikologi Sosial. Jakarta: Balai Pustaka

Slavin R, Sharan S, Kagan S, Lazarowits SH, Webb C, Schmuck R. 1985. Learning to cooperate, cooperating to learn. Plenum press. New york and London 1985 